\title{
anu \\ Mitigating the Health Effects of Aqueous Cr(VI) with Iron-Modified Biochar
}

\author{
Zhihong Zheng ${ }^{1,2}$ and Xiaohan Duan ${ }^{1, * \mathbb{D}}$ \\ 1 School of Water Conservancy, North China University of Water Resources and Electric Power, \\ Zhengzhou 450046, China; zzh@ncwu.edu.cn \\ 2 Henan Vocational College of Water Conservancy and Environment, Zhengzhou 450008, China \\ * Correspondence: b2019081505@stu.ncwu.edu.cn
}

Citation: Zheng, Z.; Duan, X. Mitigating the Health Effects of Aqueous $\mathrm{Cr}(\mathrm{VI})$ with Iron-Modified Biochar. Int. J. Environ. Res. Public Health 2022, 19, 1481. https:// doi.org/10.3390/ijerph19031481

Academic Editor: Cheng Yan

Received: 16 December 2021

Accepted: 25 January 2022

Published: 28 January 2022

Publisher's Note: MDPI stays neutral with regard to jurisdictional claims in published maps and institutional affiliations.

Copyright: (C) 2022 by the authors. Licensee MDPI, Basel, Switzerland. This article is an open access article distributed under the terms and conditions of the Creative Commons Attribution (CC BY) license (https:// creativecommons.org/licenses/by/ $4.0 /)$.
Abstract: A large amount of chromium ( $\mathrm{Cr}$ ) has entered the natural environment from the wastewater and waste residues, and the hexavalent $(\mathrm{Cr}(\mathrm{VI}))$ is highly poisonous, threatening the ecological environment and human health directly. In this study, iron-modified biochar was prepared using honeysuckle residue as raw material and the ferric chloride impregnation method. Batch $\mathrm{Cr}(\mathrm{VI})$ adsorption experiments were carried out using the modified honeysuckle-derived biochar (MHDB) as an adsorbent. The results indicate that a $\mathrm{pH}$ of 2 was best for the adsorption removal of $\mathrm{Cr}(\mathrm{VI})$ in the initial $\mathrm{pH}$ range of $2-10$. The adsorption kinetic data fitted the pseudo-second-order model best out of the two models, and the Langmuir model was better than the Freundlich model to describe the adsorption process. Thermodynamic analysis indicated that the adsorption process of $\mathrm{Cr}(\mathrm{VI})$ on MHDB had an endothermic and spontaneous nature, and the increasing temperature was conducive to the adsorption. The main mechanisms of $\mathrm{Cr}(\mathrm{VI})$ adsorption might be the physical adsorption (electrostatic interactions) and chemical adsorption (ion exchange, the reduction of $\mathrm{Cr}(\mathrm{VI})$ to $\mathrm{Cr}(\mathrm{III})$ ). The efficient adsorption of $\mathrm{Cr}(\mathrm{VI})$ makes $\mathrm{MHDB}$ a potential material for $\mathrm{Cr}(\mathrm{VI})$-containing wastewater treatment. This study provides a feasible adsorption material for mitigating the environmental hazards of chromium, which has a certain reference value for protecting environmental health.

Keywords: adsorption; environmental health; chromium; ferric chloride; traditional Chinese medicine residual

\section{Introduction}

Heavy metal pollutants have raised worldwide concerns because of their toxicity and persistence, causing an indefinite threat to the sustainable development of environmental health and human safety [1-4]. Among these heavy metals, chromium (Cr) is a commonly known pollutant derived from various industries, such as steel manufacturing, dye manufacturing, leather tanning, oil color, and electroplating [5-10]. Cr usually exists in the forms of trivalent $(\mathrm{Cr}(\mathrm{III}))$ and hexavalent $(\mathrm{Cr}(\mathrm{VI}))$ [11]. $\mathrm{Cr}(\mathrm{III})$ and $\mathrm{Cr}(\mathrm{VI})$ can be converted to each other under certain conditions [12]. $\mathrm{Cr}$ (III) is a micronutrient with low solubility and mobility that can be easily removed from water in the form of stable and insoluble precipitates [13]. In contrast, $\mathrm{Cr}(\mathrm{VI})$ is several hundred times more toxic than $\mathrm{Cr}$ (III) due to its high toxicity, higher migration, and non-biodegradability [14,15]. $\mathrm{Cr}$ (VI) has much higher mobility in water and soil and can be transformed into various reactive and toxic intermediates, eventually endangering human health because of the accumulation characteristics $[16,17]$. $\mathrm{Cr}(\mathrm{VI})$ can cause cell mutations and lead to skin injury, intestinal diseases, kidney diseases, cancer, and other diseases [18-21]. Consequently, $\mathrm{Cr}(\mathrm{VI})$ is a significant threat to the quality of water, soil environments, and human health and has been considered a top-priority pollutant to be addressed in water remediation [22]. To minimize the environmental risk caused by $\mathrm{Cr}(\mathrm{VI})$ and ensure human health, the maximum levels of chromium allowed in drinking water must not outnumber 0.05 ppm according to the 
World Health Organization (WHO) [23]. Therefore, it is of great importance to remove $\mathrm{Cr}(\mathrm{VI})$ from water safely and efficiently.

Various techniques, including chemical precipitation, ion exchange, ultrafiltration, membrane separation, adsorption, and so on, have been developed to remove $\mathrm{Cr}(\mathrm{VI})$ from water [24-26]. Among the techniques, adsorption is a promising method for $\mathrm{Cr}(\mathrm{VI})$ removal due to its low cost, simple operation, and high efficiency $[27,28]$. Biochar, considered one of the most promising adsorbents because of its low cost and excellent adsorption effect, has been used for the removal of chromium-containing wastewater successfully to protect environmental health $[29,30]$. Biochar $(\mathrm{BC})$ is obtained by the pyrolysis of biomass that is rich and diverse. Biomass made up of bagasse, corn stalk, peanut shell, oak wood, sludge, and rice straw has been used for the preparation of biochar successfully [31-35].

With the development of traditional Chinese medicine in recent years, plenty of traditional Chinese medicine residuals (TCMRs) have been created. Up to $70 \mathrm{Mt}$ of TCMRs are produced per year in China. Owing to the limited availability of effective recycling methods, TCMRs are mainly disposed of as solid waste in landfill [36]. Thus, using TCMRs as a raw material with which to prepare biochar is a promising method for its reclamation. According to the statistical data, honeysuckle is a widely used traditional Chinese medicine, which showed the best adsorption effect of $\mathrm{Cr}(\mathrm{VI})$ among ten kinds of TCMRs, including astragalus membranaceus, radix Isatidis, thorowax, and others in our pre-experiment.

In order to enhance the adsorption performance of biochar, researchers often use surface modification methods to improve the pore structure and the surface functional groups, such as chemical oxidation, chemical reduction, and metal impregnation $[37,38]$. Ferric chloride $\left(\mathrm{FeCl}_{3}\right)$ is a common chemical reagent that can provide hydrogen ions in aqueous solutions. Previous studies have indicated that modification using $\mathrm{FeCl}_{3}$ could increase the mesopores of carbon materials and that Fe oxides have great selectivity and affinity for $\mathrm{Cr}(\mathrm{VI})$ [39]. Hence, $\mathrm{FeCl}_{3}$ was chosen as a modifier to promote the $\mathrm{Cr}(\mathrm{VI})$ adsorption capacity in this study and, thus, to better reduce the harm of $\mathrm{Cr}(\mathrm{VI})$ in the environment.

Therefore, in order to prepare an effective biochar material to solve the problem of $\mathrm{Cr}(\mathrm{VI})$ in the environment, honeysuckle residue was used as a raw material to prepare honeysuckle-derived biochar (HDB), and the ferric chloride impregnation method was used to obtain modified honeysuckle-derived biochar (MHDB) to improve the adsorption capacity. The influencing factors of $\mathrm{Cr}(\mathrm{VI})$ adsorption were investigated to explore the adsorption mechanism. The study could be a valuable reference for the resource recovery of TCMRs and provide a resolvent for chromium-containing wastewater while alleviating the environmental pollution problem and protecting human health.

\section{Material and Method}

\subsection{Preparation of the Biochar and Modified Biochar}

Honeysuckle residue (HR) was obtained from a local pharmacy in Zhengzhou, China. The HR was dried at $105^{\circ} \mathrm{C}$ for $2 \mathrm{~h}$ and smashed and passed through a 60 mesh sieve. The HR particles were calcinated in a tube furnace at $400{ }^{\circ} \mathrm{C}$ for $3 \mathrm{~h}$ in a $\mathrm{N}_{2}$ environment. The black matter was taken out, ground, and screened with a 100 mesh sieve in sequence.

Ferric chloride was added to a conical flask along with HDB. The optimum concentrations of $\mathrm{Fe}^{3+}$ and the solid-liquid ratio were determined to be $1 \mathrm{~mol} / \mathrm{L}$ and 1:20 (W/V) in our pre-experiment, respectively. After vigorous stirring for $10 \mathrm{~min}$, the mixture was oscillated in a shaker at $150 \mathrm{rpm}$ for $8 \mathrm{~h}$. The product was washed with deionized water until a constant $\mathrm{pH}$ was achieved. It was then dried at $60^{\circ} \mathrm{C}$ for $12 \mathrm{~h}$ and sifted with a 100 mesh sieve to obtain the MHDB.

\subsection{Characterization Techniques}

The surface morphology of the HDB and MHDB before and after $\mathrm{Cr}(\mathrm{VI})$ adsorption was performed using a scanning electron microscope (SEM, Zeiss Genimi500, Zeiss, Barkhausenbau, Germany). The porosities and surface areas of the HDB and MHDB were 
measured using a surface area analyzer with a $\mathrm{N}_{2}$ atmosphere (BELSORP-max, MicrotracBEL, Osaka, Japan). The structures and crystallinities of the HDB and MHDB before and after $\mathrm{Cr}(\mathrm{VI})$ adsorption were characterized using an X-ray diffractometer (XRD, ZSX Primus II, Rigaku Corporation, Tokyo, Japan). The surface functional groups of HDB and MHDB before and after $\mathrm{Cr}(\mathrm{VI})$ adsorption were detected using Fourier transform infrared spectroscopy (FTIR, Thermo Fisher IS50, Thermo Fisher, Waltham, MA, USA). The elements and morphologies of the sample surface were analyzed using X-ray photoelectron spectroscopy (XPS, Thermo Scientific Escalab 250Xi+, Thermo Fisher, Waltham, MA, USA). The zeta potential of the MHDB was determined using a zeta potential meter after sonication (Particle Metrix GmbH, Particle Metrix, Munich, Germany).

\subsection{Synthesis of Cr(VI)-Containing Wastewater}

$\mathrm{Cr}(\mathrm{VI})$ solutions with different concentrations were synthesized by dissolving $\mathrm{K}_{2} \mathrm{Cr}_{2} \mathrm{O}_{7}$ into deionized water. The $\mathrm{pH}$ value of the wastewater was adjusted using $0.1 \mathrm{~mol} / \mathrm{L}$ of $\mathrm{NaOH}$ or $\mathrm{HCl}$. All chemicals used in the study were analytically pure.

\subsection{Batch Adsorption Experiment}

A total of $0.05 \mathrm{~g}$ biochar was added into $25 \mathrm{~mL}$ of $\mathrm{Cr}(\mathrm{VI})$ solution, and then the conical flasks were put into a temperature-controlled shaker and reacted at $120 \mathrm{rpm}$. At the end of the experiment, the mixture was filtered with a $0.45 \mu \mathrm{m}$ filter membrane, the residual $\mathrm{Cr}$ (VI) was determined using diphenylcarbazide spectrophotometry at $540 \mathrm{~nm}$. Each set was replicated three times, and the average value was used for subsequent analysis. The adsorption capacity was calculated by Equation (1), as follows:

$$
q=\frac{\left(C_{0}-C_{e}\right) V}{m}
$$

where $q(\mathrm{mg} / \mathrm{g})$ is the adsorption capacity; $C_{0}$ and $C_{e}(\mathrm{mg} / \mathrm{L})$ are the initial and final concentration of $\mathrm{Cr}(\mathrm{VI})$, respectively; $m(\mathrm{~g})$ is the mass of biochar used for the adsorption; $V(\mathrm{~L})$ is the solution volume.

\section{Results and Discussion}

\subsection{Sample Characterization}

\subsubsection{Scanning Electron Microscope (SEM) Images}

The SEM images of (A) HDB, (B) MHDB, and (C) MHDB after $\mathrm{Cr}(\mathrm{VI})$ adsorption are shown in Figure 1. The surface of the MHDB was rougher than that of the HDB due to the modification of ferric chloride $\left(\mathrm{FeCl}_{3}\right)$; more surface pores in circular and irregular shapes appeared. Figure $1 \mathrm{C}$ shows that more irregular particles were dispersed on the surface after adsorption, which indicates that the $\mathrm{Cr}(\mathrm{VI})$ was successfully adsorbed onto the surface of the MHDB.

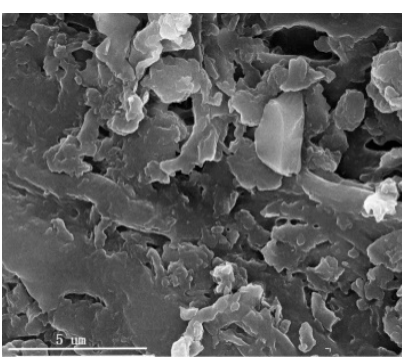

(A)

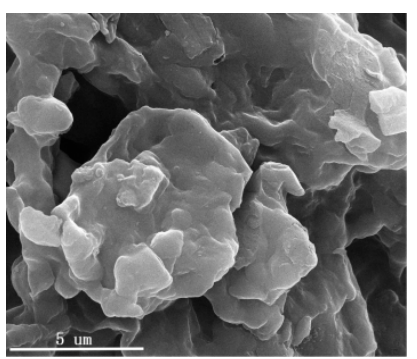

(B)

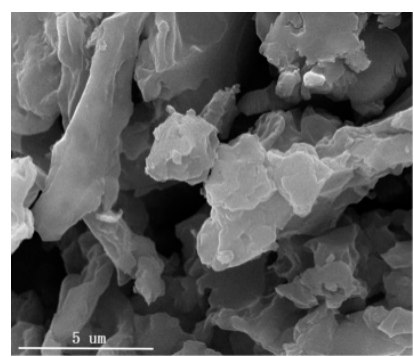

(C)

Figure 1. SEM images of (A) HDB, (B) MHDB, and (C) MHDB after adsorption of Cr(VI).

\subsubsection{Brunauer-Emmett-Teller (BET) Analysis}

Figure 2 shows the $\mathrm{N}_{2}$ sorption-desorption isotherms of HDB and MHDB, which fitted the type IV isotherm, indicating the adsorbents are mesoporous materials. The average pore 
diameters of the HDB and MHDB were $12.45 \mathrm{~nm}$ and $8.33 \mathrm{~nm}$, respectively. The hysteresis loop was at $\mathrm{p} / \mathrm{p}_{0}>0.4$, as shown in Figure 2, indicating that the capillary condensation occurred in the biochar channels at relatively high pressures. The mesopore size distribution of the HDB was unimodal, with a peak pore size of $3.718 \mathrm{~nm}$, as shown in Figure 2C. In addition, the peak pore size of the MHDB was $3.75 \mathrm{~nm}$, and multiple peaks appeared, which indicates that the number of mesopores increased after modification. Therefore, the diffusion resistance decreased and the $\mathrm{Cr}(\mathrm{VI})$ diffused more easily into the pores of the adsorbent. The BET-specific surface areas of the HDB and MHDB were $0.81 \mathrm{~m}^{2} / \mathrm{g}$ and $1.13 \mathrm{~m}^{2} / \mathrm{g}$, respectively, and the small specific surface area was mainly due to the raw material characteristics and the low sintering temperature. Considering the material properties, the mechanism of $\mathrm{Cr}(\mathrm{VI})$ adsorption might mainly be electrostatic adsorption, and the modification with iron enhanced the adsorption capacity of the adsorbent effectively.


Figure 2. Nitrogen physisorption-desorption isotherms of $\mathrm{HDB}$ (A) and MHDB (B); BJH mesopore size distributions of HDB (C) and MHDB (D).

\subsubsection{X-ray Diffractometer (XRD) Analysis}

For further study, the HDB and MHDB were characterized by XRD, and the results are shown in Figure 3A. The XRD patterns of the biochars show a large number of characteristic peaks, and the main peak is at $26.49^{\circ}$, indicating that the surface of the material contained crystalline material for $\mathrm{SiO}_{2}$. No obvious sharp peak appeared, indicating that the iron of the MHDB mainly existed with low crystallinity [40]. The small peaks of the MHDB at $2 \theta=29.45^{\circ}, 42.77^{\circ}$, and $60.05^{\circ}$ indicate that the $\mathrm{Fe}_{3} \mathrm{C}$ particles may have been present in the MHDB, which was consistent with the XPS analysis results [41,42]. In addition, the modification of the ferric chloride $\left(\mathrm{FeCl}_{3}\right)$ caused changes in the materials, according to Figures 1 and 2. It is quite clear that the surface of the original HDB was smoother than that of the MHDB, and the average pore diameter increased after modification. 


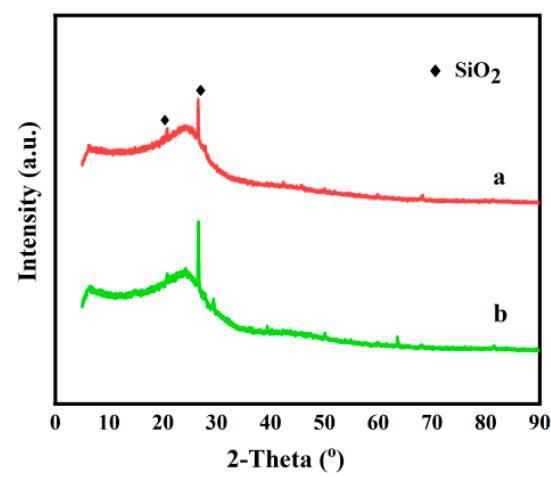

(A)



(B)

Figure 3. (A) The XRD patterns of (a) HDB and (b) MHDB; (B) FTIR spectra of (a) HDB, (b) MHDB; (c) MHDB after adsorption of $\mathrm{Cr}(\mathrm{VI})$.

\subsubsection{Fourier Transform Infrared (FTIR) Analysis}

Figure $3 \mathrm{~B}$ shows that the wavenumber at $3424 \mathrm{~cm}^{-1}$ corresponds to the stretching oscillation of $-\mathrm{OH}$, with a wide adsorption peak [43]. The wavenumbers at $2923 \mathrm{~cm}^{-1}$ and $2854 \mathrm{~cm}^{-1}$ could link to the symmetric and asymmetric stretching vibrations of $\mathrm{C}-\mathrm{H}$ and $\mathrm{C}-$ $\mathrm{C}$ double bonds. The wavenumber at $1597 \mathrm{~cm}^{-1}$ is attributed to the stretching oscillation of $\mathrm{C}=\mathrm{C}$ and $\mathrm{C}=\mathrm{O}$ double bonds. The peak at $1035 \mathrm{~cm}^{-1}$ is assigned to the stretching vibrations of $\mathrm{C}-\mathrm{O}$. Except for the common functional groups, the oxygen-containing functional groups of the MHDB could have provided more chemical adsorption sites that improved the adsorption capacity, such as Ar-H, based on the wavenumber at $873 \mathrm{~cm}^{-1}$. Meanwhile, the wavenumber at $556 \mathrm{~cm}^{-1}$ is attributed to $\mathrm{Fe}-\mathrm{O}$, indicating that the adsorbent contained Fe [44]. Figure 3B shows that the peaks for the functional groups changed after $\mathrm{Cr}(\mathrm{VI})$ adsorption, as the peak around $3424 \mathrm{~cm}^{-1}(-\mathrm{OH})$ shifted to $3406 \mathrm{~cm}^{-1}$, indicating that the functional groups were favorable for $\mathrm{Cr}(\mathrm{VI})$ removal. A new wavenumber at $2363 \mathrm{~cm}^{-1}$ appeared after adsorption, which corresponds to the formation of $\mathrm{H}_{3} \mathrm{O}^{+}$[45]. In addition, the peak near $552 \mathrm{~cm}^{-1}$ (Fe-O) obviously increased after $\mathrm{Cr}(\mathrm{VI})$ adsorption. In summary, the change in the infrared spectrum after adsorption resulted from chemical denaturation, which indicates that the adsorption process was accompanied by a chemisorption reaction. The adsorption effect was closely related to the functional groups on the surface of the adsorbent, and the addition of functional groups by modification could have enhanced the adsorption.

\subsubsection{X-ray Photoelectron Spectroscopy (XPS) Analysis}

The full XPS spectra of the (a) HDB, (b) MHDB, and (c) MHDB after adsorption of $\mathrm{Cr}(\mathrm{VI})$ are shown in Figure $4 \mathrm{~A}$. The $\mathrm{C} 1 \mathrm{~s}$ spectra of the HDB resolved into two peaks at $284 \mathrm{eV}$ and $287.82 \mathrm{eV}$, representing the $\mathrm{C}-\mathrm{H}$ and $\mathrm{C}=\mathrm{O}$, respectively [46,47]. The $\mathrm{O} 1 \mathrm{~s}$ spectra of the HDB resolved into two peaks at $532.29 \mathrm{eV}$ and $533.1 \mathrm{eV}$, representing the $-\mathrm{OH}$ and C-O, respectively $[48,49]$. The binding energies and intensities of the peaks changed after modification, suggesting that the structure of the MHDB changed due to the iron modification. As shown in Figure 4B, the major peaks in the Fe 2p spectra are at $711.1 \mathrm{eV}$ (Fe 2p3/2) and $724.3 \mathrm{eV}(\mathrm{Fe} 2 \mathrm{p} 1 / 2)$ [50]. The distinctive satellite peaks at $705.9 \mathrm{eV}$ and $719.8 \mathrm{eV}$ are assigned to $\mathrm{Fe}_{3} \mathrm{C}$, which is in agreement with a previous study [51]. After the adsorption of $\mathrm{Cr}(\mathrm{VI})$, the main peaks shifted to $711.4 \mathrm{eV}$ and $725.1 \mathrm{eV}$, respectively, indicating that the iron was involved in the adsorption. As shown in Figure $4 \mathrm{C}$, the binding energies at $576.8 \mathrm{eV}(\mathrm{Cr} 2 \mathrm{p} 3 / 2)$ and $586.7 \mathrm{eV}(\mathrm{Cr} 2 \mathrm{p} 1 / 2)$ correspond to $\mathrm{Cr}(\mathrm{III})$, and the peaks of $579.0 \mathrm{eV}(\mathrm{Cr} 2 \mathrm{p} 3 / 2)$ and $588.3 \mathrm{eV}(\mathrm{Cr} 2 \mathrm{p} 1 / 2)$ correspond to $\mathrm{Cr}(\mathrm{VI})$ [52,53]. Hence, the MHDB could have effectively reduced the $\mathrm{Cr}(\mathrm{VI})$ concentration in the water, converting the $\mathrm{Cr}(\mathrm{VI})$ to the stable $\mathrm{Cr}(\mathrm{III})$. At this point, the toxicity and harm of $\mathrm{Cr}(\mathrm{VI})$ to human health declines sharply after adsorption. 


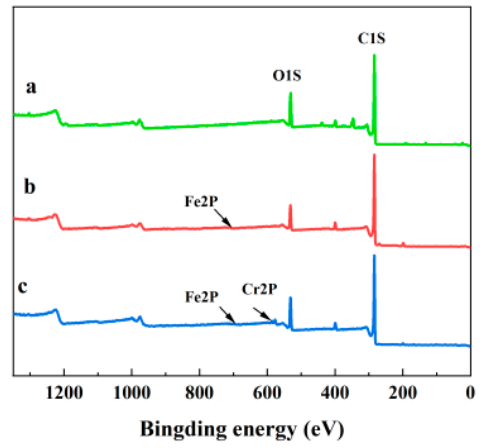

(A)



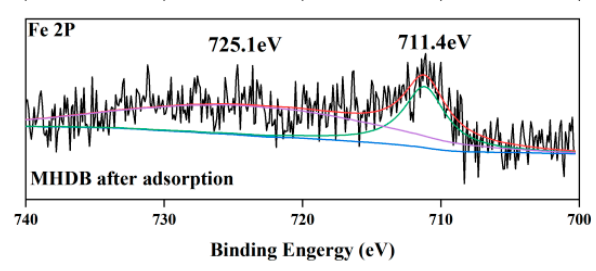

(B)

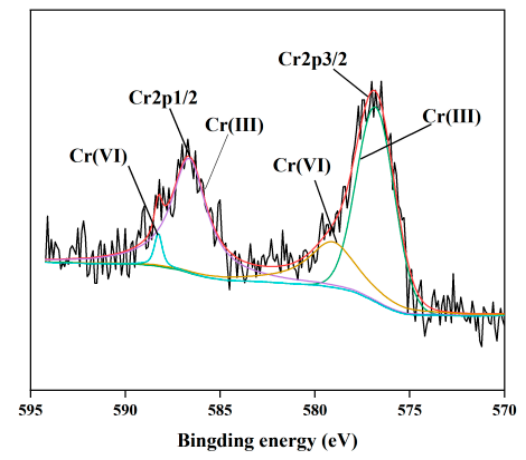

(C)

Figure 4. (A) The full XPS spectra of (a) HDB, (b) MHDB, (c) MHDB after adsorption; (B) detailed graph of the $\mathrm{Fe} 2 \mathrm{p}$ before and after adsorption; $(\mathrm{C})$ detailed graph of the $\mathrm{Cr} 2 \mathrm{p}$ after adsorption.

In sum, the sample characterization results suggest that the MHDB changed after the $\mathrm{Cr}(\mathrm{VI})$ adsorption, and the main mechanisms of the $\mathrm{Cr}(\mathrm{VI})$ adsorption might be physical adsorption (electrostatic interactions) and chemical adsorption (ion exchange, the reduction of $\mathrm{Cr}(\mathrm{VI})$ to $\mathrm{Cr}(\mathrm{III}))$.

\subsection{Adsorption Study}

\subsubsection{Effect of Initial Solution $\mathrm{pH}$}

The effect of the initial aqueous $\mathrm{pH}$ on the adsorption of $\mathrm{Cr}(\mathrm{VI})$ was studied by varying the initial $\mathrm{pH}$ from 2 to 10 . Figure $5 \mathrm{~A}$ showed the adsorption capacity of $\mathrm{Cr}(\mathrm{VI})$ by the MHDB decreased with the increasing $\mathrm{pH}$, which is consistent with the results of a previous study [54]. The $\mathrm{Cr}(\mathrm{VI})$ adsorption capacity decreased slowly from $8.10 \mathrm{mg} / \mathrm{g}$ to $7.39 \mathrm{mg} / \mathrm{g}$ as the initial $\mathrm{pH}$ increased slowly from 2 to 6 , and then the adsorption capacity decreased to $5.23 \mathrm{mg} / \mathrm{g}$ quickly as the initial $\mathrm{pH}$ rose to 10 .

Previous studies have shown that the $\mathrm{pH}$ causes changes in the surface charge of the biochar and the degree of protonation of the functional groups on the biochar, affecting the form of $\mathrm{Cr}(\mathrm{VI})$ in the adsorption system significantly [55]. The main forms of chromium were $\mathrm{CrO}_{4}{ }^{2-}$ and $\mathrm{HCrO}_{4}{ }^{-}$in the $\mathrm{pH}$ range of 2-8. Further research has shown that $\mathrm{HCrO}_{4}{ }^{-}$ was the main form, with $\mathrm{pH}$ values of $2-6.5$, and the form of $\mathrm{CrO}_{4}{ }^{2-}$ mainly presented in water at $\mathrm{pH}$ values of $>6.5$ (Figure 5B) [56]. In addition, the free energy of the $\mathrm{HCrO}_{4}{ }^{-}$was low, meaning it could be removed from the system more easily. 


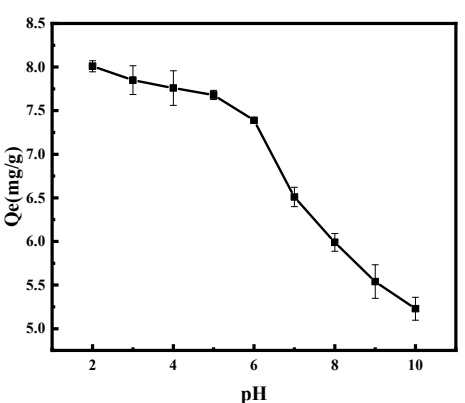

(A)

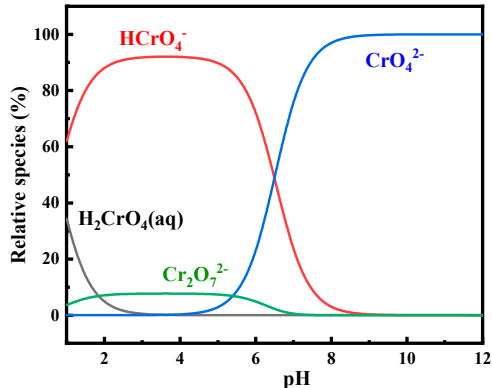

(B)

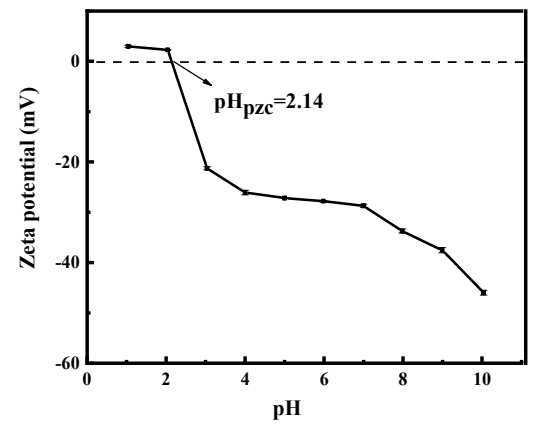

(C)

Figure 5. (A) Effect of initial solution $\mathrm{pH}$ on adsorption performance $\left(C_{0}=50 \mathrm{mg} / \mathrm{L}\right.$, time $=6 \mathrm{~h}$, and temperature $\left.=25^{\circ} \mathrm{C}\right)$; (B) the existing forms of $\mathrm{Cr}(\mathrm{VI})$ in the solution at different $\mathrm{pH}$ levels; (C) zeta potential of MHDB.

The dominant chemical reactions of the reduction of $\mathrm{Cr}(\mathrm{VI})$ to $\mathrm{Cr}(\mathrm{III})$ in the solution are expressed as Equations (2) and (3) [57]. As seen in Figure 5C, the $\mathrm{pH}_{\mathrm{PZC}}$ value of the MHDB was measured to be 2.14, which indicates that the surface charge of the MHDB was positive at solution $\mathrm{pH}$ values lower than its $\mathrm{pH}$ PZC. The highest removal efficiency at a $\mathrm{pH}$ of 2 was due to the possible protonation of the adsorbent, which led to the weakening of the electrostatic repulsion and the enhancement of the electrostatic adsorption of $\mathrm{Cr}(\mathrm{VI})$ [58]. The protons in the solution were depleted, and the positive charge of the adsorbent surface turned into a negative charge as the initial $\mathrm{pH}$ increased; hence, the electrostatic attraction with $\mathrm{Cr}(\mathrm{VI})$ decreased. With the initial $\mathrm{pH}$ increase, the alkaline environment meant an increased presence of $\mathrm{OH}^{-}$, which indicates that the equilibrium in Equations (2) and (3) shifted to the left. That is, the alkaline environment suppressed the conversion reaction of $\mathrm{Cr}(\mathrm{VI})$ to $\mathrm{Cr}(\mathrm{III})$ and was detrimental to the removal of $\mathrm{Cr}(\mathrm{VI})$. The experiment results indicate that a lower $\mathrm{pH}$ was beneficial for $\mathrm{Cr}(\mathrm{VI})$ removal, and a $\mathrm{pH}$ of 2 was best for $\mathrm{Cr}(\mathrm{VI})$ adsorption by MHDB in the $\mathrm{pH}$ range of 2-10. Therefore, the severe threat of $\mathrm{Cr}(\mathrm{VI})$ to human health is mitigated by MHDB more effectively in an acidic environment.

$$
\begin{gathered}
\mathrm{Cr}_{2} \mathrm{O}_{7}{ }^{2-}+14 \mathrm{H}^{+}+6 \mathrm{e}^{-} \rightarrow 2 \mathrm{Cr}^{3+}+7 \mathrm{H}_{2} \mathrm{O} \\
\mathrm{HCrO}_{4}{ }^{-}+7 \mathrm{H}^{+}+3 \mathrm{e}^{-} \rightarrow \mathrm{Cr}^{3+}+4 \mathrm{H}_{2} \mathrm{O}
\end{gathered}
$$

\subsubsection{Effect of Adsorption Time and Adsorption Kinetics}

The adsorption of $\mathrm{Cr}(\mathrm{VI})$ was affected by the adsorption time, and the result is illustrated in Figure 6A. It can be seen that $\mathrm{Cr}(\mathrm{VI})$ adsorption increased with the increase in reaction time, and the $\mathrm{Cr}(\mathrm{VI})$ adsorption took place in two stages. The adsorption capacities in the first $12 \mathrm{~h}$ rapidly reached $91.65 \%$ and $76.65 \%$ of the equilibrium adsorption capacity with the initial $\mathrm{Cr}(\mathrm{VI})$ concentrations of 10 and $50 \mathrm{mg} / \mathrm{L}$, respectively. In the second stage, the removal rate showed slow growth, and the adsorption of $\mathrm{Cr}(\mathrm{VI})$ reached equilibrium at $48 \mathrm{~h}$. The active sites of the adsorbent were unbound in the early stage, meaning it could 
combine with $\mathrm{Cr}(\mathrm{VI})$ quickly. Most of the active sites were occupied along with the reaction time, which led to slow adsorption and the equilibrium of the adsorption at $48 \mathrm{~h}$.

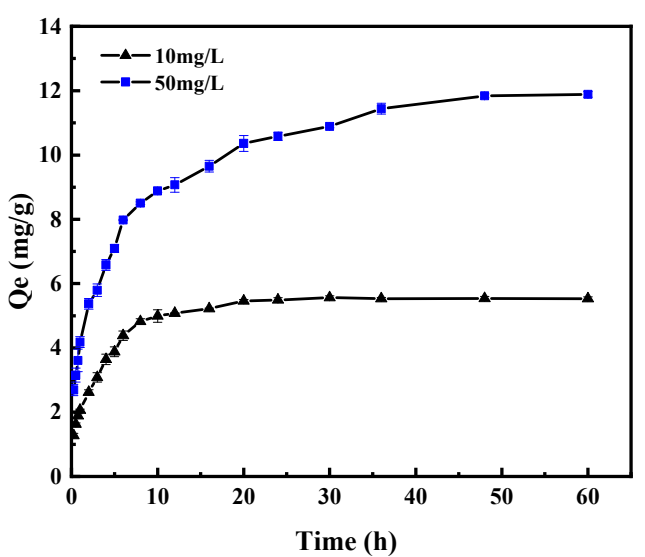

(A)
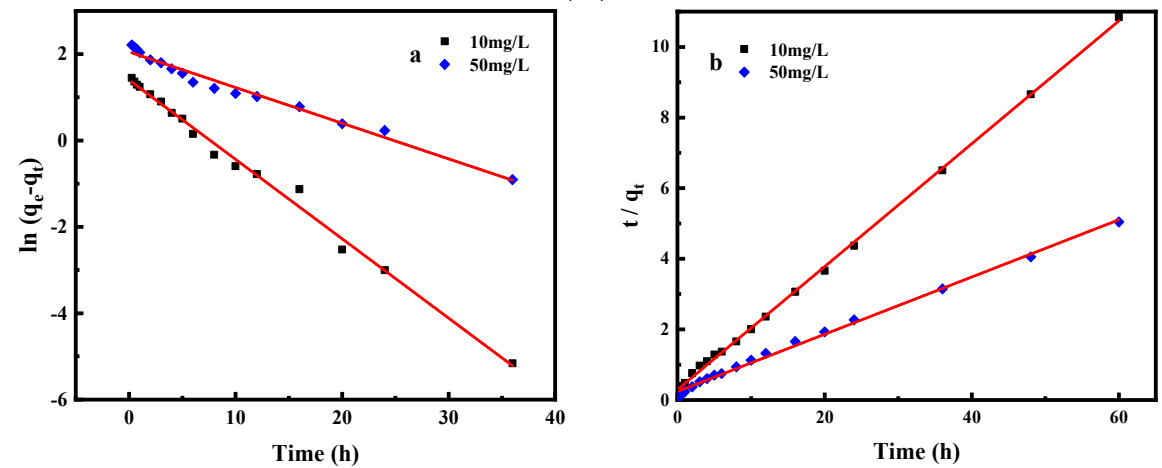

(B)

Figure 6. (A) Effect of adsorption time on adsorption performance $\left(C_{0}=10\right.$ and $50 \mathrm{mg} / \mathrm{L}, \mathrm{pH}=2$, and temperature $\left.=25^{\circ} \mathrm{C}\right) ;(\mathbf{B})$ Linear kinetic plots of pseudo-first model (a) and pseudo-second model (b) for $\mathrm{Cr}(\mathrm{VI})$ adsorption by MHDB.

Pseudo-first-order and pseudo-second-order models were used to fit the data obtained from the experiment [59]. The two Equations (4) and (5) are expressed as follows:

$$
\begin{gathered}
\ln \left(q_{e}-q_{t}\right)=\ln q_{e}-k_{1} t \\
\frac{t}{q_{t}}=\frac{t}{q_{e}}+\frac{1}{k_{2} q_{e}^{2}}
\end{gathered}
$$

where $q_{t}$ and $q_{e}(\mathrm{mg} / \mathrm{g})$ are the $\mathrm{Cr}(\mathrm{VI})$ uptakes at time $t$ and at equilibrium time, respectively; $k_{1}\left(\mathrm{~h}^{-1}\right)$ is the equilibrium rate constant, and $k_{2}[\mathrm{~g} /(\mathrm{mg} \cdot \mathrm{h})]$ is the equilibrium rate constant, respectively.

Figure $6 \mathrm{~B}$ shows the linear kinetic plots of the two models, and the kinetics parameters for the adsorption are listed in Table 1 . It can be seen that the regression coefficient of the pseudo-second-order equation is higher out of the two equations $\left(\mathrm{R}^{2}>0.993\right)$. Moreover, the adsorption amounts calculated based on the pseudo-second-order equation at a different initial concentration of $\mathrm{Cr}(\mathrm{VI})$ were 5.74 and $12.33 \mathrm{mg} / \mathrm{g}$, which are in good agreement with the experimental data at 5.54 and $11.84 \mathrm{mg} / \mathrm{g}$, respectively. In sum, the pseudo-secondorder equation was better to describe the adsorption process of $\mathrm{Cr}(\mathrm{VI})$ by $\mathrm{MHDB}$, and the human health impact of $\mathrm{Cr}(\mathrm{VI})$ was weakened after adsorption. 
Table 1. The kinetics parameters for the adsorption of $\mathrm{Cr}(\mathrm{VI})$ by MHDB.

\begin{tabular}{ccccccc}
\hline \multirow{2}{*}{$C_{\mathbf{0}}$} & \multicolumn{3}{c}{ Pseudo-First-Order } & \multicolumn{3}{c}{ Pseudo-Second-Order } \\
\cline { 2 - 7 } $\mathbf{m g} \mathbf{L}$ & $\boldsymbol{q}_{\boldsymbol{e}}$ & $\boldsymbol{k}_{\mathbf{1}}$ & $\boldsymbol{R}^{\mathbf{2}}$ & $\boldsymbol{q}_{\boldsymbol{e}}$ & $\boldsymbol{k}_{\mathbf{2}}$ & $\boldsymbol{R}^{\mathbf{2}}$ \\
\hline 10 & 4.05 & 0.1838 & 0.9925 & 5.74 & 0.1741 & 0.9991 \\
50 & 7.78 & 0.0826 & 0.9789 & 12.33 & 0.0811 & 0.9962 \\
\hline
\end{tabular}

\subsubsection{Adsorption Isotherms}

As the initial $\mathrm{Cr}(\mathrm{VI})$ concentration increased from 10 to $100 \mathrm{mg} / \mathrm{L}$, the uptake of $\mathrm{Cr}(\mathrm{VI})$ by MHDB increased from 4.96 to $9.93 \mathrm{mg} / \mathrm{g}$, from 5.13 to $11.68 \mathrm{mg} / \mathrm{g}$, and from 5.17 to $13.70 \mathrm{mg} / \mathrm{g}$ at 15,25 , and $35^{\circ} \mathrm{C}$, respectively (Figure $7 \mathrm{~A}$ ). The results might be attributed to the fact that the concentration difference between the adsorbent and the solution obviously increased when the initial $\mathrm{Cr}(\mathrm{VI})$ concentration increased. In this respect, the difference accelerated the mass transfer rate and promoted the adsorption reaction of $\mathrm{Cr}(\mathrm{VI})$.



(A)
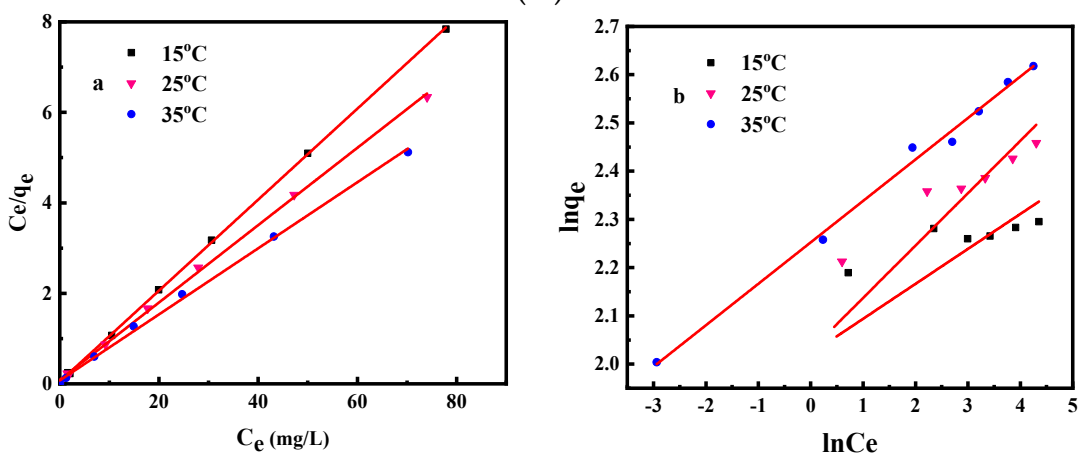

(B)

Figure 7. (A) Isotherms of $\mathrm{Cr}(\mathrm{VI})$ adsorption removal by $\mathrm{MHDB}\left(C_{0}=10-100 \mathrm{mg} / \mathrm{L}, \mathrm{pH}=2\right.$, time $=$ $48 \mathrm{~h}$, and temperature $=15,25$ and $\left.35^{\circ} \mathrm{C}\right) ;(\mathbf{B})$ adsorption isotherms of $\mathrm{Cr}(\mathrm{VI})$ by fitting the Langmuir isotherm model (a) and Freundlich isotherm model (b).

Figure 7A shows the relationship between the $\mathrm{Cr}(\mathrm{VI})$ concentration and the adsorption capacity of the MHDB at equilibrium. In addition, the adsorption isotherm data were fitted by the Langmuir and Freundlich models [60]. The linearized forms of the two models are expressed by Equations (6) and (7) below:

$$
\begin{aligned}
\frac{C_{e}}{q_{e}} & =\frac{1}{Q_{m} K_{L}}+\frac{C_{e}}{Q_{m}} \\
\ln q_{e} & =\ln K_{f}+\frac{1}{n} \ln C_{e}
\end{aligned}
$$


where $C_{e}(\mathrm{mg} / \mathrm{L})$ and $q_{e}(\mathrm{mg} / \mathrm{g})$ are the concentration and adsorption capacity at equilibrium, respectively; $K_{L}(\mathrm{~L} / \mathrm{mg})$ is the Langmuir constant related to the binding energy, and $Q_{m}(\mathrm{mg} / \mathrm{g})$ is the maximum adsorption capacity; $K_{f}$ is the Freundlich constant related to the adsorption capacity, and $n$ is the adsorption intensity.

Figure 7B shows the fitting results of the Langmuir and Freundlich models, and the isotherm parameters are listed in Table 2 . The regression coefficients $\mathrm{R}^{2}$ of the Langmuir equation were higher than those of the Freundlich equation at temperatures of 15, 25, and $35{ }^{\circ} \mathrm{C}$, indicating that the Langmuir equation was more suitable for describing the adsorption process $\left(\mathrm{R}^{2}>0.997\right)$, and the adsorption of $\mathrm{Cr}(\mathrm{VI})$ by MHDB had a monolayer adsorption nature. Though other isotherm models might offer further insight, considering that the Langmuir equation was significantly suitable for the adsorption process, other isotherm models were no longer used for analysis in this study. Based on the Langmuir isotherm model, the calculated maximum adsorptions were 9.95, 11.70, and $13.70 \mathrm{mg} / \mathrm{g}$ at 15,25 , and $35^{\circ} \mathrm{C}$, respectively. In sum, the impact of $\mathrm{Cr}(\mathrm{VI})$ on human health declined more easily by MHDB at higher temperatures.

Table 2. The parameters of Langmuir equation and Freundlich equation.

\begin{tabular}{ccccccc}
\hline $\begin{array}{c}\text { Reaction } \\
\text { Temperature }\end{array}$ & \multicolumn{3}{c}{ Langmuir Equation } & \multicolumn{3}{c}{ Freundlich Equation } \\
\cline { 2 - 7 }${ }^{\circ} \mathbf{C}$ & $\boldsymbol{Q}_{\boldsymbol{m}}$ & $\boldsymbol{K}_{\boldsymbol{L}}$ & $\boldsymbol{R}^{\mathbf{2}}$ & $\boldsymbol{K}_{\boldsymbol{f}}$ & $\mathbf{1} \boldsymbol{n}$ & $\boldsymbol{R}^{\mathbf{2}}$ \\
\hline 15 & 9.95 & 2.039 & 0.9998 & 7.551 & 0.0724 & 0.5089 \\
25 & 11.70 & 0.972 & 0.9989 & 7.605 & 0.1085 & 0.7089 \\
35 & 13.70 & 0.979 & 0.9979 & 9.511 & 0.0859 & 0.9924 \\
\hline
\end{tabular}

The maximum adsorption capacity of the MHDB was about $13.70 \mathrm{mg} / \mathrm{g}$ at $35{ }^{\circ} \mathrm{C}$, which was higher than those of multiple other types of biochars from previous studies. For instance, the adsorption capacities of $\mathrm{Cr}(\mathrm{VI})$ by the pineapple peel-derived biochar, the natural zeolite-derived biochar, the nano-magnetite-modified biochar material, and the cornstalk-derived biochar were $7.44 \mathrm{mg} / \mathrm{g}, 6.08 \mathrm{mg} / \mathrm{g}, 9.92 \mathrm{mg} / \mathrm{g}$, and $9.25 \mathrm{mg} / \mathrm{g}$, respectively [61-64]. Thus, the modified honeysuckle-derived biochar is a promising adsorbent for $\mathrm{Cr}(\mathrm{VI})$ removal and could be a valuable reference for the resource recovery of TCMRs, alleviating the environmental pollution problem from the chromium-containing wastewater.

\subsubsection{Adsorption Thermodynamics}

The thermodynamics of $\mathrm{Cr}(\mathrm{VI})$ adsorbed by MHDB were studied at $288 \mathrm{~K}, 298 \mathrm{~K}$, and $308 \mathrm{~K}$, and the parameters were calculated using Equations (8)-(10), as follows [65]:

$$
\begin{gathered}
\Delta G^{0}=\Delta H^{0}-T \Delta S^{0} \\
\ln K_{d}=\frac{\Delta S^{0}}{R}+\frac{\Delta H^{0}}{R T} \\
K_{d}=\frac{q_{e}}{C_{e}}
\end{gathered}
$$

where $K_{d}$ is the distribution coefficient $(\mathrm{L} / \mathrm{g})$; the $K_{d}$ value is obtained by plotting $\ln \left(q_{e} / C_{e}\right)$ against $C_{e}$ and extrapolating to zero $C_{e} ; \Delta S^{0}$ is the standard entropy change $(\mathrm{kJ} / \mathrm{mol} \cdot \mathrm{K})$; $\Delta H^{0}$ is the standard enthalpy change $(\mathrm{kJ} / \mathrm{mol}) ; R$ is the ideal gas constant $(8.314 \mathrm{~J} \mathrm{~mol} / \mathrm{k})$; $T$ is the reaction temperature $(K) ; \Delta G^{0}$ is the standard Gibbs free energy change $(\mathrm{kJ} / \mathrm{mol})$; $C_{e}$ is the concentration of $\mathrm{Cr}(\mathrm{VI})$ at equilibrium $(\mathrm{mg} / \mathrm{L}) ; q_{e}$ is the adsorption capacity of MHDB on $\mathrm{Cr}(\mathrm{VI})$ at equilibrium $(\mathrm{mg} / \mathrm{g})$.

Figure 8 shows the relationship between the $1 / T$ and $\ln K_{d}$. The values of $\Delta S^{0}, \Delta H^{0}$, and $\Delta G^{0}$ are shown in Table 3 . It can be seen that the adsorption process had a spontaneous character since all three values of $\Delta G^{0}$ at 288,298 , and $308 K$ were negative. Meanwhile, the spontaneous nature of the adsorption process increased since the value of $\Delta G^{0}$ decreased 
gradually as the temperature increased. The higher temperature was favorable for the adsorption of $\mathrm{Cr}(\mathrm{VI})$ by $\mathrm{MHDB}$ due to the fact that the high reaction temperature decreased the solution viscosity and the diffusion resistance of $\mathrm{Cr}(\mathrm{VI})$ ions, which could speed up the adsorption process. Thus, the higher temperature was beneficial for lessening the harmful effects of $\mathrm{Cr}(\mathrm{VI})$ on human health.

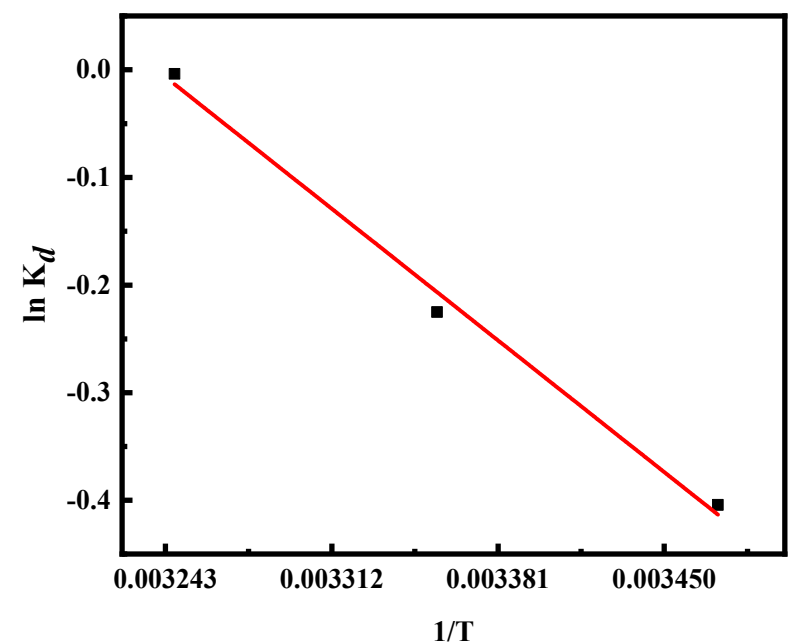

Figure 8. Thermodynamics plot for adsorption of $\mathrm{Cr}(\mathrm{VI})$ by MHDB.

Table 3. Thermodynamic parameters for adsorption of Cr(VI) by MHDB.

\begin{tabular}{cccc}
\hline Reaction Temperature & $\Delta G^{\mathbf{0}}$ & $\Delta \boldsymbol{H}^{\mathbf{0}}$ & $\Delta \boldsymbol{S}^{\mathbf{0}}$ \\
\hline $288 \mathrm{~K}$ & -0.15 & & \\
$298 \mathrm{~K}$ & -0.67 & 14.74 & 51.73 \\
$308 \mathrm{~K}$ & -1.19 & & \\
\hline
\end{tabular}

\subsubsection{Effect of Co-Existing Ions}

In general, wastewater may contain other anions that could influence the adsorption of $\mathrm{Cr}$ (VI). Therefore, the impact of co-existing ions on the adsorption of $\mathrm{Cr}(\mathrm{VI})$ was investigated in this study, and the results are shown in Figure 9. It can be seen that the adsorption capacity of $\mathrm{Cr}(\mathrm{VI})$ decreased with the presence of anions, and the effect of $\mathrm{PO}_{4}{ }^{3-}$ was the most significant among the three anions. In addition, the adsorption capacity of $\mathrm{Cr}$ (VI) decreased with the increase of the anion concentration. As shown in Figure 9, the $\mathrm{PO}_{4}{ }^{3-}$ with a high concentration $(0.1 \mathrm{~mol} / \mathrm{L})$ significantly inhibited $\mathrm{Cr}(\mathrm{VI})$ removal, and the adsorption capacity of $\mathrm{Cr}(\mathrm{VI})$ decreased to $4.68 \mathrm{mg} / \mathrm{g}$ - a decrease of $61.20 \%$.

The competition between anions and $\mathrm{Cr}(\mathrm{VI})$ for adsorption might mainly be due to their similar ionic nature; the anions occupied the active sites on the surface of the adsorbent and formed complexes $[66,67]$. The interference was directly proportional to the charge on the anions; the anionic charges provided by the anions $\mathrm{Cl}^{-}, \mathrm{SO}_{4}{ }^{2-}$, and $\mathrm{PO}_{4}{ }^{3-}$ were -1 , -2 , and -3 , respectively, and hence, the negative effects on the $\mathrm{Cr}(\mathrm{VI})$ removal efficiency followed the order of $\mathrm{Cl}^{-}<\mathrm{SO}_{4}{ }^{2-}<\mathrm{PO}_{4}{ }^{3-}$. Overall, these results suggest that the presence of anions could affect the removal of $\mathrm{Cr}(\mathrm{VI})$ by $\mathrm{MHDB}$, and the impact was positively related to the charges and concentrations of the anions. Therefore, the anions reduced the adsorption capacity of the MHDB for $\mathrm{Cr}(\mathrm{VI})$; in other words, they increased the harmful effects of $\mathrm{Cr}(\mathrm{VI})$ on human health. 


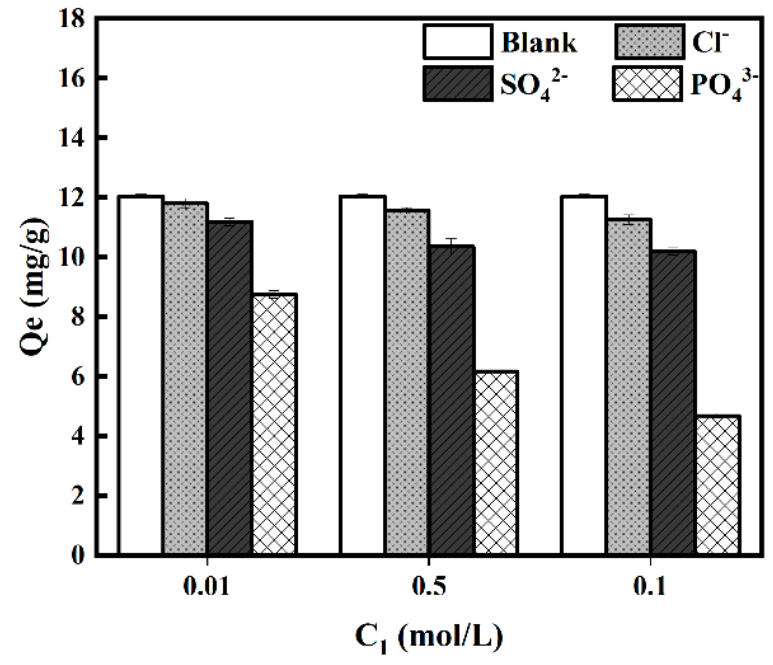

Figure 9. Effect of co-existing ions on adsorption performance $\left(C_{0}=150 \mathrm{mg} / \mathrm{L}\right.$, time $=6 \mathrm{~h}, \mathrm{pH}=2$, temperature $=25^{\circ} \mathrm{C}$ ).

\section{Conclusions}

Hexavalent chromium $(\mathrm{Cr}(\mathrm{VI}))$ is a severe threat to human health. In order to solve the hazard of chromium in the environment, the removal of $\mathrm{Cr}(\mathrm{VI})$ using $\mathrm{Fe}^{3+}$-modified honeysuckle-derived biochar (MHDB) was researched in this study. The highest $\mathrm{Cr}(\mathrm{VI})$ removal was observed at a $\mathrm{pH}$ of 2 in the initial $\mathrm{pH}$ range of $2-10$. The adsorption of $\mathrm{Cr}(\mathrm{VI})$ took place in two stages; the removal efficiency increased rapidly in the first $12 \mathrm{~h}$, and then increased slowly until the equilibrium was reached. The adsorption process followed pseudo-second-order kinetics and the Langmuir isotherm. The thermodynamic study showed that the adsorption process was spontaneous and endothermic. The anions had negative effects on $\mathrm{Cr}(\mathrm{VI})$ adsorption in the order of $\mathrm{Cl}^{-}<\mathrm{SO}_{4}{ }^{2-}<\mathrm{PO}_{4}{ }^{3-}$. Based on the experimental results, the MHDB reduced the $\mathrm{Cr}(\mathrm{VI})$ concentration in water distinctly, demonstrating a high adsorption capacity and an efficient ability to convert the $\mathrm{Cr}(\mathrm{VI})$ to the $\mathrm{Cr}(\mathrm{III})$. In general, this study provides a new material for the adsorption of $\mathrm{Cr}(\mathrm{VI})$ and has important reference value for mitigating the harm of chromium pollution and protecting environmental health.

Author Contributions: Conceptualization, Z.Z. and X.D.; methodology, Z.Z. and X.D.; investigation, X.D.; supervision, Z.Z.; writing—original draft, X.D.; writing—review and editing, Z.Z. and X.D. All authors have read and agreed to the published version of the manuscript.

Funding: The authors are thankful for the financial support from the Major Science and Technology Project in Henan Province of China for the integration and demonstration of sewage treatment technology for typical villages and towns of Henan Province (161100310700).

Institutional Review Board Statement: Not applicable.

Informed Consent Statement: Not applicable.

Acknowledgments: The authors thank the Director of laboratory in North China University of Water Resources and Electric Power for offering the experiment sites and experiment materials.

Conflicts of Interest: The authors declare no conflict of interest.

\section{References}

1. $\mathrm{Hu}, \mathrm{X}$.; Zhao, H.P.; Liang, Y.; Chen, R. Energy level mediation of $(\mathrm{BiO})_{2} \mathrm{CO}_{3}$ via $\mathrm{Br}$ doping for effificient molecular oxygen activation and ciproflfloxacin photodegradation. Appl. Catal. B Environ. 2019, 258, 117966. [CrossRef]

2. Mao, W.; Zhang, L.X.; Liu, Y.; Wang, T.Y.; Bai, Y.C.; Guan, Y.T. Facile assembled N, S-codoped corn straw biochar loaded Bi ${ }_{2} \mathrm{WO}_{6}$ with the enhanced electron-rich feature for the efficient photocatalytic removal of ciprofloxacin and $\mathrm{Cr}(\mathrm{VI})$. Chemosphere 2021, 263, 127988. [CrossRef] [PubMed] 
3. Yuan, R.R.; Yue, C.L.; Qiu, J.L.; Liu, F.Q.; Li, A.M. Highly effificient sunlight-driven reduction of Cr(VI) by TiO $\mathrm{T}_{2} @ \mathrm{NH}_{2}-\mathrm{MIL}-88 \mathrm{~B}(\mathrm{Fe})$ heterostructures under neutral conditions. Appl. Catal. B Environ. 2019, 251, 229-239. [CrossRef]

4. Seleiman, M.F.; Santanen, A.; Mäkelä, P.S.A. Recycling sludge on cropland as fertilizer-Advantages and risks. Resour. Conserv. Recycl. 2020, 155, 104647. [CrossRef]

5. $\quad$ Dong, H.R.; He, Q.; Zeng, G.M.; Tang, L.; Zhang, C.; Xie, Y.K.; Zeng, Y.L.; Zhao, F.; Wu, Y.A. Chromate removal by surfacemodifified nanoscale zero-valent iron: Effect of different surface coatings and water chemistry. J. Colloid Interface Sci. 2016, 471, 7-13. [CrossRef]

6. Kong, Q.P.; Wei, J.Y.; Hu, Y.; Wei, C.H. Fabrication of terminal amino hyperbranched polymer modified graphene oxide and its prominent adsorption performance towards Cr(VI). J. Hazard. Mater. 2019, 363, 161-169. [CrossRef]

7. Antony, G.S.; Manna, A.; Baskaran, S.; Puhazhendi, P.; Ramchary, A.; Niraikulam, A.; Ramudu, K.N. Non-enzymatic reduction of $\mathrm{Cr}(\mathrm{VI})$ and it's effective biosorption using heat-inactivated biomass: A fermentation waste material. J. Hazard. Mater. 2020, 392, 122257. [CrossRef]

8. Shan, R.; Shi, Y.Y.; Gu, J.; Bi, J.W.; Yuan, H.R.; Luo, B.; Chen, Y. Aqueous Cr(VI) removal by biochar derived from waste mangosteen shells: Role of pyrolysis and modifification on its absorption process. J. Environ. Chem. Eng. 2020, 8, 103885. [CrossRef]

9. Lu, Z.; Zhang, H.; Shahab, A.; Zhang, K.; Zeng, H.T.; Bacha, A.; Nabi, I.; Ullah, H. Comparative study on characterization and adsorption properties of phosphoric acid activated biochar and nitrogen-containing modified biochar employing Eucalyptus as a precursor. J. Clean. Prod. 2021, 303, 127046. [CrossRef]

10. Seleiman, M.F.; Ali, S.; Refay, Y.; Rizwan, M.; Alhammad, B.A.; El-Hendawy, S.E. Chromium resistant microbes and melatonin reduced $\mathrm{Cr}$ uptake and toxicity, improved physio-biochemical traits and yield of wheat in contaminated soil. Chemosphere $\mathbf{2 0 2 0}$. [CrossRef]

11. Shi, Y.; Shan, R.; Lu, L.; Yuan, H.; Jiang, H.; Zhang, Y.; Chen, Y. High-efficiency removal of Cr(VI) by modified biochar derived from glue residue. J. Clean. 2020, 254, 119935. [CrossRef]

12. Richard, F.C.; Bourg, A.C.M. Aqueous geochemistry of chromium: A review. Water Res. 1991, 25, 807-816. [CrossRef]

13. Su, C.L.; Wang, S.; Zhou, Z.Y.; Wang, H.J.; Xie, X.J.; Yang, Y.Y.; Feng, Y.; Liu, W.F.; Liu, P. Chemical processes of Cr(VI) removal by Fe-modified biochar under aerobic and anaerobic conditions and mechanism characterization under aerobic conditions using synchrotron-related techniques. Sci. Total Environ. 2021, 768, 144604. [CrossRef] [PubMed]

14. Zhao, J.J.; Boada, R.; Cibin, C.; Palet, C. Enhancement of selective adsorption of Cr species via modifification of pine biomass. Sci. Total Environ. 2021, 756, 143816. [CrossRef]

15. Zhu, D.C.; Shao, J.G.; Li, Z.Q.; Yang, H.P.; Zhang, S.H.; Chen, H.P. Nano nickel embedded in N-doped CNTs-supported porous biochar for adsorption-reduction of hexavalent chromium. J. Hazard. Mater. 2021, 416, 125693. [CrossRef]

16. Khalil, U.; Shakoor, M.B.; Ali, S.; Alyemeni, M.N.; Wijaya, L. Adsorption-reduction performance of tea waste and rice husk biochars for Cr(VI) elimination from wastewater. J. Saudi Chem. Soc. 2020, 24, 799-810. [CrossRef]

17. Lv, Z.M.; Tian, X.L.; Wang, C.H.; Alsaedi, A.; Hayat, T.; Chen, C.L. Metal-organic frameworks-derived 3D yolk shell-like structure $\mathrm{Ni@carbon}$ as a recyclable catalyst for Cr(VI) reduction. Chem. Eng. J. 2020, 389, 123428. [CrossRef]

18. Wang, X.S.; Tang, Y.P.; Tao, S.R. Kinetics, equilibrium and thermodynamic study on removal of Cr (VI) from aqueous solutions using low-cost adsorbent Alligator weed. Chem. Eng. J. 2009, 148, 217-225. [CrossRef]

19. Kahraman, H.T.; Pehlivan, E. $\mathrm{Cr}^{6+}$ rovemal using oleaster (Elaeagnus) seed and cherry (Prunus avium) stone biochar. Powder Technol. 2017, 306, 61-67. [CrossRef]

20. Zhong, J.W.; Yin, W.Z.; Li, Y.T.; Li, P.; Wu, J.H.; Jiang, G.B.; Gu, J.J.; Liang, H. Column study of enhanced Cr(VI) removal and longevity by coupled abiotic and biotic processes using Fe0 and mixed anaerobic culture. Water Res. 2017, 122, 536-544. [CrossRef]

21. Rafique, M.I.; Usman, A.R.; Ahmad, M.; Al-Wabel, M.I. Immobilization and mitigation of chromium toxicity in aqueous solutions and tannery waste-contaminated soil using biochar and polymer-modified biochar. Chemosphere 2021, 266, 129198. [CrossRef] [PubMed]

22. He, B.; Yun, Z.J.; Shi, J.B.; Jiang, G.B. Research progress of heavy metal pollution in China: Sources, analytical methods, status, and toxicity. Chin. Sci. Bull. 2013, 58, 134-140. [CrossRef]

23. WHO. Guidelines for Drinking-Water Quality: Fourth Edition Incorporating the First Addendum; World Health Organization: Geneva, Switzerland, 2017.

24. Basumatary, A.K.; Kumar, R.V.; Ghoshal, A.K.; Pugazhenthi, G. Cross flow ultrafiltration of Cr (VI) using MCM-41, MCM-48 and Faujasite (FAU) zeolite-ceramic composite membranes. Chemosphere 2016, 153, 436-446. [CrossRef] [PubMed]

25. Pakade, V.E.; Tavengwa, N.T.; Madikizela, L.M. Recent advances in hexavalent chromium removal from aqueous solutions by adsorptive methods. RSC Adv. 2019, 9, 26142-26164. [CrossRef]

26. Tiadi, N.; Dash, R.R.; Mohanty, C.R.; Patel, A.M. Comparative Studies of Adsorption of Chromium(VI) Ions onto Different Industrial Wastes. J. Hazard. Toxic Radioact. Waste 2020, 24, 04020021. [CrossRef]

27. Rodrigues, E.; Almeida, O.; Brasil, H.; Moraes, D.; Reis, M.A.L. Adsorption of chromium(VI) on hydrotalcitehydroxyapatite material doped with carbon nanotubes: Equilibrium, kinetic and thermodynamic study. Appl. Clay Sci. 2019, 172, 57-64. [CrossRef]

28. Jiang, R.Q.; Yu, G.W.; Ndagijimana, P.; Wang, Y.; You, F.T.; Xing, Z.J.; Wang, Y. Effective adsorption of Direct Red 23 by sludge biochar based adsorbent: Adsorption kinetics, thermodynamics and mechanisms study. Water Sci. Technol. 2021, 83, 2424-2436. [CrossRef] 
29. Roy, P.; Dey, U.; Chattoraj, S.; Mukhopadhyay, D.; Mondal, N.K. Modeling of the adsorptive removal of arsenic(III) using plant biomass: A bioremedial approach. Appl. Water Sci. 2017, 7, 1307-1321. [CrossRef]

30. Dong, H.R.; Deng, J.M.; Xie, Y.K.; Zhang, C.; Jiang, Z.; Cheng, Y.J.; Hou, K.J.; Zeng, G.M. Stabilization of nanoscale zero-valent iron (nZVI) with modified biochar for $\mathrm{Cr}(\mathrm{VI})$ removal from aqueous solution. J. Hazard. Mater. 2017, 332, 79-86. [CrossRef]

31. Yang, C.; Ge, C.Z.; Li, X.L.; Li, L.; Wang, B.; Lin, A.J.; Yang, W.J. Does soluble starch improve the removal of Cr(VI) by nZVI loaded on biochar? Ecotoxicol. Environ. Saf. 2021, 208, 111552. [CrossRef]

32. Yin, Z.H.; Liu, Y.G.; Liu, S.B.; Jiang, L.H.; Tan, X.F.; Zeng, G.M.; Li, M.F.; Liu, S.J.; Tian, S.R.; Fang, Y. Activated magnetic biochar by one-step synthesis: Enhanced adsorption and coadsorption for 17 $\beta$-estradiol and copper. Sci. Total Environ. 2018, 639, 1530-1542. [CrossRef] [PubMed]

33. Zhao, Y.L.; Zhang, R.Y.; Liu, H.B.; Li, M.X.; Chen, T.H.; Chen, D.; Zou, X.H.; Frost, R.L. Green preparation of magnetic biochar for the effective accumulation of $\mathrm{Pb}(\mathrm{II})$ : Performance and mechanism. Chem. Eng. J. 2019, 375, 122011. [CrossRef]

34. Lyu, H.H.; Tang, J.C.; Huang, Y.; Gai, L.S.; Zeng, E.Y.; Liber, K.; Gong, Y.Y. Removal of hexavalent chromium from aqueous solutions by a novel biochar supported nanoscale iron sulfide composite. Chem. Eng. J. 2017, 322, 516-524. [CrossRef]

35. Zhang, Y.T.; Jiao, X.Q.; Liu, N.; Lv, J.; Yang, Y.D. Enhanced removal of aqueous Cr( VI) by a green synthesized nano scale zero-valent iron supported on oak wood biochar. Chemosphere 2020, 245, 125542. [CrossRef] [PubMed]

36. Guo, F.Q.; Dong, Y.P.; Zhang, T.H.; Dong, L.; Guo, C.W.; Rao, Z.H. Experimental Study on Herb Residue Gasifification in an Air-Blown Circulating Fluidized Bed Gasififier. Ind. Eng. Chem. Res. 2014, 53, 13264-13273. [CrossRef]

37. Zeng, H.T.; Zeng, H.Z.; Zhang, H.; Shahab, A.; Zhang, K.; Lu, Y.Q.; Nabi, I.; Naseem, F.; Ullah, H. Efficient adsorption of Cr (VI) from aqueous environments by phosphoric acid activated eucalyptus biochar. J. Clean. Prod. 2021, 286, 124964. [CrossRef]

38. Lee, Y.G.; Shin, J.W.; Kwak, J.W.; Kim, S.W.; Son, C.J.; Kim, G.Y.; Lee, C.H.; Chon, K.M. Enhanced Adsorption Capacities of Fungicides Using Peanut Shell Biochar via Successive Chemical Modifification with $\mathrm{KMnO}_{4}$ and KOH. Separations 2021, 8, 52. [CrossRef]

39. Feng, Z.Y.; Chen, N.; Feng, C.P.; Gao, Y. Mechanisms of $\mathrm{Cr}(\mathrm{VI})$ removal by $\mathrm{FeCl}_{3}$-modifified lotus stem-based biochar (FeCl $@$ @LSBC) using mass-balance and functional group expressions. Colloids Surf. A Physicochem. Eng. Asp. 2018, 551, 17-24. [CrossRef]

40. Zhong, Z.X.; Yu, G.W.; Mo, W.T.; Zhang, C.J.; Huang, H.; Li, S.; Gao, M.; Lu, X.J.; Zhang, B.P.; Zhu, H.P. Enhanced phosphate sequestration by Fe(III) modifified biochar derived from coconut shell. RSC Adv. 2019, 9, 10425. [CrossRef]

41. Cho, D.; Yoon, K.; Kwon, E.E.; Biswas, J.K.; Song, H. Fabrication of magnetic biochar as a treatment medium for As(V) via pyrolysis of $\mathrm{FeCl}_{3}$-pretreated spent coffee ground. Environ. Pollut. 2017, 229, 942-949. [CrossRef]

42. Hou, T.Y.; Sun, X.H.; Xie, D.L.; Wang, M.J.; Fan, A.; Chen, Y.Y.; Shu, C.; Zheng, C.M.; Hu, W.B. Mesoporous Graphitic Carbon-Encapsulated $\mathrm{Fe}_{2} \mathrm{O}_{3}$ Nanocomposite as High-Rate Anode Material for Sodium-Ion Batteries. Chem.-A Eur. J. 2018, 24, 14786-14793. [CrossRef] [PubMed]

43. Liang, M.; Ding, Y.M.; Zhang, Q.; Wang, D.Q.; Li, H.H.; Lu, L. Removal of aqueous Cr(VI) by magnetic biochar derived from bagasse. Sci. Rep. 2020, 10, 21473. [CrossRef] [PubMed]

44. Zhu, S.S.; Ho, S.; Huang, X.C.; Wang, D.W.; Yang, F.; Wang, L.; Wang, C.Y.; Cao, X.D.; Ma, F. Magnetic Nanoscale Zerovalent Iron Assisted Biochar: Interfacial Chemical Behaviors and Heavy Metals Remediation Performance. ACS Sustain. Chem. Eng. 2017, 5 , 9673-9682. [CrossRef]

45. Yang, L.; Chen, J.P. Biosorption of hexavalent chromium onto raw and chemically modified Sargassum sp. Bioresour. Technol. 2008, 99, 297-307. [CrossRef]

46. Guo, J.H.; Yan, C.Z.; Luo, Z.X.; Fang, H.D.; Hu, S.G.; Cao, Y.L. Synthesis of a novel ternary HA/Fe-Mn oxide-loaded biochar composite and its application in cadmium(II) and arsenic(V) adsorption. J. Environ. Sci. 2019, 85, 168-176. [CrossRef] [PubMed]

47. Zhang, R.C.; Leivisk, T.; Taskila, S.; Tanskanen, J. Iron-loaded Sphagnum moss extract residue for phosphate removal. J. Environ. Manag. 2018, 218, 271-279. [CrossRef]

48. De, S.H.; Mishra, S.; Poonguzhali, E.; Rajesh, M.; Tamilarasan, K. Fractionation and characterization of lignin from waste rice straw: Biomass surface chemical composition analysis. Int. J. Biol. Macromol. 2020, 145, 795-803. [CrossRef]

49. Benis, K.Z.; Soltan, J.; Mcphedran, K.N. Electrochemically modified adsorbents for treatment of aqueous arsenic: Pore diffusion in modified biomass vs. Biochar. Chem. Eng. J. 2021, 423, 130061. [CrossRef]

50. Zhang, B.A.Q.; Zhao, Z.W.; Chen, N.; Feng, C.P.; Lei, Z.F.; Zhang, Z.Y. Insight into effificient phosphorus removal/recovery from enhanced methane production of waste activated sludge with chitosan-Fe supplementation. Water Res. 2020, 187, 116427. [CrossRef]

51. Liang, Y.; Liu, P.; Xiao, J.; Li, H.B.; Wang, C.X.; Yang, G.W. A microfifibre assembly of an iron-carbon composite with giant magnetisation. Sci. Rep. 2013, 3, 3051. [CrossRef]

52. Wang, Z.W.; Wu, T.; Geng, X.; Ru, J.J.; Hua, Y.X.; Bu, J.J.; Xue, Y.; Wang, D. The role of electrolyte ratio in electrodeposition of nanoscale Fe-Cr alloy from choline chloride-ethylene glycol ionic liquid: A suitable layer for corrosion resistance. J. Mol. Liq. 2021. [CrossRef]

53. Zhou, M.; Yang, X.N.; Sun, R.H.; Wang, X.Z.; Yin, W.Q.; Wang, S.S.; Wang, J. The contribution of lignocellulosic constituents to $\mathrm{Cr}(\mathrm{VI})$ reduction capacity of biochar-supported zerovalent iron. Chemosphere 2021, 263, 127871. [CrossRef] [PubMed]

54. Zhao, G.X.; Huang, X.B.; Tang, Z.W.; Huang, Q.F.; Niu, F.L.; Wang, X.K. Polymer-based nanocomposites for heavy metal ions removal from aqueous solution: A review. Polym. Chem. 2018, 9, 3562-3582. [CrossRef] 
55. Qu, J.H.; Tian, X.; Jiang, Z.; Cao, B.; Akindolie, M.S.; Hu, Q.; Feng, C.C.; Feng, Y.; Meng, X.L.; Zhang, Y. Multi-component adsorption of $\mathrm{Pb}(\mathrm{II}), \mathrm{Cd}(\mathrm{II})$ and $\mathrm{Ni}(\mathrm{II})$ onto microwave-functionalized cellulose: Kinetics, isotherms, thermodynamics, mechanisms and application for electroplating wastewater purifification. J. Hazard. Mater. 2020, 387, 121718. [CrossRef]

56. Liu, K.; Li, F.B.; Tian, Q.W.; Nie, C.R.; Ma, Y.B.; Zhu, Z.L.; Fang, L.P.; Huang, Y.Y.; Liu, S.W. A highly porous animal bone-derived char with a superiority of promoting nZVI for Cr(VI) sequestration in agricultural soils. J. Environ. Sci. 2021, 104, 27-39. [CrossRef] [PubMed]

57. Mahanty, B.; Mondal, S. Synthesis of Magnetic Biochar Using Agricultural Waste for the Separation of Cr(VI) From Aqueous Solution. Arab. J. Sci. Eng. 2021, 46, 10803-10818. [CrossRef]

58. Zhao, Z.G.; Wei, J.X.; Li, F.X.; Qu, X.L.; Liang, S.; Zhang, H.D.; Yu, Q.J. Synthesis, characterization and hexavalent chromium adsorption characteristics of Aluminum and sucrose-incorporated tobermorite. Materials. 2017, 10, 597. [CrossRef]

59. Xu, H.; Gao, M.X.; Hu, X.; Chen, Y.H.; Li, Y.; Xu, X.Y.; Zhang, R.Q.; Yang, X.; Tang, C.F.; Hu, X.J. A novel preparation of S-nZVI and its high efficient removal of $\mathrm{Cr}(\mathrm{VI})$ in aqueous solution. J. Hazard. Mater. 2021, 416, 125924. [CrossRef]

60. Rezak, N.; Bahmani, A.; Bettahar, N. Adsorptive removal of $\mathrm{P}(\mathrm{V})$ and $\mathrm{Cr}(\mathrm{VI})$ by calcined Zn-Al-Fe ternary LDHs. Water Sci. Technol. 2021, 83, 2504-2517. [CrossRef]

61. Wang, C.H.; Gu, L.F.; Liu, X.Y.; Zhang, X.Y.; Cao, L.; Hu, X.X. Sorption behavior of Cr(VI) on pineapple-peel-derived biochar and the inflfluence of coexisting pyrene. Int. Biodeterior. Biodegrad. 2016, 111, 78-84. [CrossRef]

62. Deveci, H.; Kar, Y. Adsorption of hexavalent chromium from aqueous solutions by bio-chars obtained during biomass pyrolysis. J. Ind. Eng. Chem. 2013, 19, 190-196. [CrossRef]

63. Song, X.; Zhang, Y.; Cao, N.; Sun, D.; Zhang, Z.; Wang, Y.; Wen, Y.; Yang, Y.; Lyu, T. Sustainable Chromium (VI) Removal from Contaminated Groundwater Using Nano-Magnetite-Modifified Biochar via Rapid Microwave Synthesis. Molecules 2021, $26,103$. [CrossRef] [PubMed]

64. Tang, W.; Zanli, B.L.G.L.; Chen, J. O/N/P-doped biochar induced to enhance adsorption of sulfonamide with coexisting $\mathrm{Cu}^{2+} / \mathrm{Cr}$ (VI) by air pre-oxidation. Bioresour. Technol. 2021, 341, 125794. [CrossRef] [PubMed]

65. Qhubu, M.C.; Mgidlana, L.G.; Madikizela, L.M.; Pakade, V.E. Preparation, characterization and application of activated clay biochar composite for removal of $\mathrm{Cr}(\mathrm{VI})$ in water: Isotherms, kinetics and thermodynamics. Mater. Chem. Phys. 2020, $260,124165$. [CrossRef]

66. Zhu, S.H.; Wang, S.; Yang, X.; Tufail, S.; Chen, C.; Wang, X.; Shang, J.Y. Green Sustainable and Highly Efficient Hematite Nanoparticles Modified Biochar-clay Granular Composite for Cr(VI) Removal and Related Mechanism. J. Clean. Prod. 2020, 276, 123009. [CrossRef]

67. Zhao, N.; Zhao, C.F.; Tsang, D.C.W.; Liu, K.Y.; Zhu, L.; Zhang, W.H.; Zhang, J.; Tang, Y.T.; Qiu, R.L. Microscopic mechanism about the selective adsorption of $\mathrm{Cr}(\mathrm{VI})$ from salt solution on O-rich and N-rich biochars. J. Hazard. Mater. 2021, 404, 124162. [CrossRef] [PubMed] 